\title{
The Role of Informal Education in Preserving the Culture
}

\author{
A.R. Putra ${ }^{\mathrm{a}}$,Widodo \\ ${ }^{\mathrm{a}}$ Researcher of Javanese Cultural Art, Surabaya, Indonesia \\ ${ }^{\mathrm{b}}$ Universitas Negeri Surabaya, Surabaya, Indonesia
}

\begin{abstract}
The focus of this research is how the pattern of informal educa-tion on family education preserves the art of Karawitan. This study used a case study approach done through several following stages; data collection, data reduction, data presentation and ver-ification, and data conclusion. Meanwhile, to check the validity of the data, the techniques used were credibility, transparency, de-pendability, and confirmability. The results showed that the family inculcated the culture art of Karawitan to their children who performed in several stages. The stages included instill basic learning that included attitudes, knowledge and skills. The con-clusion deals with the role of Informal Education in the family in order to preserve Karawitan by giving first experience in child-hood, to guarantee the children's emotional life, to form moral education for the children, to play as the foundation of religion, to become the friend of discussion and the source of information for the children related to Karawitan as a cultural art.
\end{abstract}

\section{Keywords-informal education, preserving culture}

\section{INTRODUCTION (HEADING 1)}

According to Law No. 202003 article 1, education is a conscious and managed effort to create an atmosphere of learning and learning process for students to be actively developed their potential to gain spiritual religion power, selfcontrol, personality, intelligence, character and skills which are needed by the students themselves, the society, nation and the country. Based on the definition above, it can be said that education is useful for obtaining personality and noble charac-ter. Therefore, education is broad and being expanded as it is not limited to school environment or formal context merely but also in all places.

Informal education is the oldest knowledge, attitude and skills transformation process in human civilization. Informal education also has a broad range and diverse types of activi-ties for all age levels targeted. In the Indonesian Law No. 202003 concerning National Education System, it is stated that informal education through family education and the environment with activities are carried out by families and in the form of independent learning activities. Informal education in the family is commonly referred as family education dealing with the transfer of knowledge, skills, attitudes, and behaviors of children to generally use the affection, care, errands, prohibition, and guidance. Then, the family makes a group based on the region of residence and descent. Later, they adopt the transmission which is done in family life to the group. For ex- ample, farming or livestock skills acquired by children from parents through learning by doing (Sudjana, 2004; Kindervetter, 1979).

This knowledge transfer activities undertaken to derive the culture to the generations. A culture is strongly important to be taught to the offspring or to the next generation so that the culture is not lost or becomes extinct. One of the ways to preserve a culture is teach the children about it. The current modern children more happy playing smartphone individually rather than playing with their friends. This condition became the beginning of the local culture loss, namely the ignorance to the local culture karawitan. Slowly, the local culture began to be abandoned, and when something like this continued then it is not possible that the local culture will be lost. Meanwhile, most of the parents currently think that by providing advanced technologies to their children is a good thing, since the technology development will develop as the time goes by following the ages. In fact, the development of technology does not always have positive impacts for children, but also negative effects for them.

Herkovist (in Sulasman \& Gumilar, 2013) stated that culture is a super-organic part of an environment that is created by human heredity from one generation to another. The art of Karawitan are part of human life which were created through a hereditary process for generation. Karawitan for children in the Jono village, such as Margisiswi group, becomes a part of efforts to conserve the older generation's culture to the young ones, from parents to their children. The participants or musician performers consists of elementary school students. There are 12 children who practice every Saturday and Sunday. However, the time is not fixed due to the children's condition because at certain hours they have their own routine activities such as reciting Koran.

The background above formulated a research problem onhow the informal education in family preserves the art of Karawitan. The objective of this research was to find out how parents transform the knowledge, attitudes and skills of karawitan to the children. The research objective was to describe and explain the role of family education in the process of transferring knowledge, attitudes and skills in order conserve Karawitan to the children. 


\section{METHOD}

This study used qualitative approach in which the researcher was the main instrument to understand the behavior of the individuals or informants who became the research objects, both in the form of "explicit knowledge" or "tacit knowledge" because a qualitative study allowed a description of the whole and deep behavior [8,1]. The data collection was carried through in-depth interview technique, participant observation, and documentation. The data analysis process started from describing the data available from all sources. The steps taken covered data reduction, data display, as well as verification and conclusions. After that, the credibility, dependability, conformability, and transferability would be tested.

\section{RESULTS AND DISCUSSION}

Research results is the description of the meaning of the analysis process. The results showed that the family played an important role in the process of transferring knowledge, attitudes and skills Karawitan art in order to conserve the culture. A family has an important role in the conservation of Karawitan. The discussion of the findings was engaged to the theories with references associated. The followings were the results of the analysis:

\section{A. The Role of Family Education to Art Karawitan conservation.}

Family education is a lifetime process that lasts through-out the ages so that every family member acquires values, attitudes, skills and knowledge that come from the experience of everyday life, environmental influences including the influence of family life, relations with neighbors, environmental work and play, market, library and the mass media as stated by Coombs (in Marturti, 2009). In addition, family education course has specific functions. A good family education course lead all family functions to work well.

Karmadi stated that the conservation of local culture can take place on an ongoing basis based on the internal strength, local strength, and the self-supporting power, therefore it deals with the necessary watchers, doers, drivers, and support from all parties. One of society layers that plays a role in the conservation of culture is family. Cultural conservation can be done if one of them carries out education within the family. Furthermore, Marzuki (2010) provides explanation concern-ing with family education such as giving first experience in childhood. Moreover, family education can ensure the child's emotional life, shape moral education in the family in which family is an institution that acts as a foundation of religious education and parents become friends of discussion and resources for children about everything [7].

\section{1) Giving first experience of musical arts in children.}

Kleis (in Sulasman \& Gumilar, 2013) argued that the experiences interpreted or explained by older people or peer was categorized as an informal education. Based on the observations and interviews conducted in the field with the informants of the parents having child as a musical player, it can be explained that the family had given the child's first experience. The given experience was not only about everyday life, but also about how to introduce children to karawitan. The parents' expectation in this case was that their child would be able to know karawitan although the child was unable to play it yet.

\section{2) Ensuring the child's emotional life.}

Tirtarahardja said that the atmosphere of family life is the best place to carry out personal education (individualized education) and social education. Family is the perfect place to realize the function of education in the self-formation of a person, not just for children but also for adolescence period. There were various kinds of parents' efforts in shaping children's social lives through personal formation that begins at an early age. One example was about the frequent use of the polite Javanese or Kromo inggil in every time they talk to the parents or older people. It could be done by taking the children as often as possible to visit the residence of the grandparents. Besides, guaranteeing the child's emotional life was also proven by the way people control their children when they were watching television, because watching television nowadays is no longer educating.

\section{3) Child's moral education formation.}

The moral education which was performed by parents in the family was identical that it dealt with teaching the children manners towards everyone. It was directly related with the child's manner in playing cultural music. When they had to deal with their lengsung instructors who were much older than them, of course they should be courteous. It is in line with what is said by Homby (in Umiarso \& Makmur, 2010) that moral is a set of principles which respect of right and wrong, good and bad, the ability to understand the difference be-tween right and wrong, teaching or the description of good be-havior. Parents taught their children to always respect his sen-ior when studying musical and use boso-kromo when facing older people. The manners were taught to use the polite lan-guage when they are talking with older people alone. Moreo-ver, the children should be able to put themselves in the com-munity and know how to respect others (Jeffs, T \& Smith, M, 2005).

\section{4) Family as the basic institution of religious education.}

Ki Hajar Dewantara (in Sudiapermana, 2012) said that family education place more perfect nature and manifesta-tions than other centers, to advance toward intelligence char-acter education (formation of individual character) and make provisions for social life. Intelligence manners here is one of forms of planting religious grounds in children.

The role of the family in religion education has been clearly illustrated in the interviews conducted by the researchers. Similar to what Mrs. Maslikah expressed, that she always took her son to worship together. Through that way, she hoped that her son would get used to pray in congregation since it gained enormous reward. In contrast to Mrs. Maslikah, Mr. Sahli gave responsibility of teaching the children religious education to his wife because he himself was rarely at home. Mr. Sahli argued that religious education was important, so that the only thing that he could do was always guiding his children. When it was 
the time to recite, they must set off on time. He trusted his wife to do so to his children as well as en-gaging them into religious education institutions outside the family such as the religious learning and schools.

\section{5) Parents' common discussion and resources for children}

Coombs (in Martuti, 2009) said that family education is a lifetime process that lasts throughout the ages so that every-one acquires values, attitudes, skills and knowledge that comes from the experience of everyday life, environmental influences including the influence of family life, relations with neighbors, work and play environment, markets, libraries and mass media. Children could obtain maximum family educa-tion if the parents were willing to share their previous experi-ences with their children.

Mr. Maliki and Mrs. Maslikah gave opinions according to their experiences, Mrs. Maslikah was trying to be a friend to her child through in the daily activities, at home or while practicing karawitan, she always threw jokes and taught to cook when the school is off. Sometimes, she gave some jokes to her child during cooking. In contrast to Mr. Maliki, he was trying to be a friend for his child. At the time of practicing kara-witan, he created a relaxing atmosphere for children to make them comfortable in practicing Karawitan together with their parents. Actually, what Mr. Maliki did was giving some jokes during the musical practice. He practiced the voice of women while his child was singing that made the children laugh and more familiar with him.

\section{B. The Patterns of Informal Education in Karawitan Arts conservation}

The transformation process inculcated (George, 2010) the culture of art Karawitan from parents to children which was carried out in several stages. The first stage is including the building of basic learning which covered attitude, knowledge as well as skills. Attitude included pleasure, cultural sense of belonging, and a sense of pride to culture. Cultural values included 'nrimo' (acquisition) of nature, obedience to parents, end emphasis on loving Karawitan that would be a special skill that was beneficial for the child. Meanwhile, the knowledge and skills included karawitan knowledge came from questioning and discussion with parents, possession of the basic skills of karawitan through randomly trying. The second stage was the transformation of knowledge, attitudes and skills of Karawitan was conducted in groups. The role of the parents was crucial when studying karawitan musical arts in groups. They could start from playing the instrument properly, harmonize the tone of the music with the other in-struments, as well as sharpen the sensitivity in playing kara-witan instrument. The third stage was advancing the practice which started to deliver autonomous study with the objective of practicing playing an instrument skill. In this stage, the chil-dren began to find it hard to play karawitan, but, it gave them a pride that 'they have the ability' to do so. The fourth stage was evaluation of cultured ability. Various training was given in order to facilitate karawitan skill advancement. Then, it was continued by doing the 'smoothing' or harmonizing the beats and knowing how to play a musical instrument as well as feel the sense of 'enjoy' in playing karawitan. The fifth stage, was called the independence. In this stage, the children were free to play instruments (gamelan) in group independent-ly. It was considered as a good team if they could play a mu-sical harmoniously and pleasantly.

The informal education in the family dealing conserve Karawitan art could play an important role by providing the first experience for children in the musical play, ensuring the child's musical emotional life, moral education, the founda-tion of religion, and becoming discussion partners for children. Therefore, the karawitan conservation efforts could be achieved due to the process of informal education in the family and the reception of a positive response from the child. The stages of the transformation of knowledge, attitudes and Karawitan skills art were presented furthermore.

\section{CONCLUSIONS}

The role of informal education in the family is crucial to the conservation of the art of Karawitan by providing the first experience, ensuring the the child's emotional life, educating child's moral, building foundation of religion aspects, discussion and resources for children in relation to Karawitan.

\section{REFERENCES}

[1] S. Arikunto, Prosedur Penelitian Suatu Pendekatan Praktek, Jakarta: Asdi Mahasatya, 2010

[2] George William Collage Facilitating Informal Education and Community Learning. London: YMCA, 2010.

[3] T. Jeffs and M. Smith, Informal Education-Conversation, Democracy and Learning. Notingham: educational Heritics press, 2005.

[4] S. Kindervatter, Nonformal Education as An Empowering Process With Case Studies From Indonesia and Thailand. USA Massachusetts, 1979

[5] Knowles at al. The Adult Learner; The Devinitive Classic in Adult Education and Human Resource Development (sixth edition). USA: Elsevier, 2005.

[6] A. Martuti, Pendidik Cerdas dan Mencerdaskan, Yogyakarta: Kreasi Wacana, 2009.

[7] S. Marzuki, Pendidikan Nonformal. Bandung : Remaja Rosdakarya, 2010.

[8] Y. Riyanto, Metodologi Penelitian Penelitian Kuantitatif dan Kualitatif. Surabaya: Unesa University Press, 2007.

[9] E. Sudiapermana, Pendidikan Keluarga Sumberdaya Pendidikan Nonformal dan Informal, Bandung: Edukasia Press, 2012.

[10] Sudjana, Djuju. Pendidikan Nonformal. Bandung: Falah Production, 2001

[11] Sulasman \& Gumilar, Teori-teori Kebudayaan, Bandung: Pustaka Setia, 2013.

[12] Umiarso and H.F. Makmur, Pendidikan Islam: Krisis Moralisme Masyarakat Modern, Yogyakarta: IRCiS, 2010. 